\title{
Alterations in the Leucocytes and Serum Biochemistry in Grey Mullet (Mugil cephalus L,) Fingerlings Exposed to Sub lethal Doses of Lead for Different Exposure Periods
}

Hussien M El-Shafei*

General Authority for Fish Resource Development, Egypt

\begin{abstract}
Grey Mullet Mugil cephalus L, fingerlings were chronically exposed to sub lethal concentrations of lead $(\mathrm{Pb})$ ( 0.1 and $0.4 \mathrm{mg} / \mathrm{L}$ for twenty-eight. The changes in the leucocytes and serum glucose, protein, and total cholesterol of the fish were determined every seven days in a renewable static bioassay system. At the end of the study, these parameters were significantly $(p<0.05)$ elevated in the $\mathrm{Pb}$ - exposed groups when compared with the control group. Showing a pronounced leuocytosis in the $\mathrm{Pb}$-exposed fish. The magnitude of increase was influenced by increasing of exposure period and $\mathrm{Pb}$ concentration. The $\mathrm{Pb}$ exposed fish were significantly $(\mathrm{p}<0.05)$ hyperglycemic and hyperbcholesteremic. The serum glucose levels on the $7^{\text {th }}$ day were $26.50 \pm 2.12 \mathrm{~g} / \mathrm{dL}$ and $30.50 \pm 0.70 \mathrm{~g} / \mathrm{dL}$ in the fish exposed to 0.1 and $0.4 \mathrm{mg} \mathrm{Pb} / \mathrm{L}$ respectively. On the $28^{\text {th }}$ day, the serum glucose concentrations were $52.50 \pm 2.12$ and $70.00 \pm 2.83 \mathrm{~g} \mathrm{~Pb} / \mathrm{dL}$ in the groups exposed to 0.1 and $0.4 \mathrm{mg} \mathrm{Pb} / \mathrm{L}$, respectively. The cholesterol concentration increased from $113.5 \pm 3.53 \mathrm{mg} \mathrm{Pb} / \mathrm{dL}$ on day 7 to $208.0 \pm 1.80 \mathrm{mg} / \mathrm{dL}$ on day 28 in the group exposed to $0.1 \mathrm{mg} \mathrm{Pb} / \mathrm{L}$. When the fish was exposed to $0.4 \mathrm{mg} \mathrm{Pb} / \mathrm{L}$ lead acetate, the cholesterol concentration increased from $131.5 \pm 3.54$ in the first week to $288 \pm 5.19 \mathrm{mg} \mathrm{Pb} / \mathrm{dL}$ on $28^{\text {th }}$ day of the study. The serum protein concentration was also significantly $(\mathrm{p}<0.05)$ increased in the $\mathrm{Pb}$ - exposed groups when compared with the control group, it increased from $4.04 \pm 0.06 \mathrm{mg} \mathrm{Pb} / \mathrm{dL}$ on day 7 to $5.30 \pm 0.05 \mathrm{mg} / \mathrm{dL}$ on day 28 in the fish exposed to $0.1 \mathrm{mg} \mathrm{Pb} / \mathrm{L}$. When the fish treated with $0.4 \mathrm{mg} \mathrm{Pb} / \mathrm{L}$, the serum protein increased from $4.45 \pm 0.37 \mathrm{mg} / \mathrm{dL}$ on day 7 to $6.18 \pm 0.19$ $\mathrm{mg} \mathrm{Pb} / \mathrm{dL}$ on day 28 , respectively. These changes are indicative of stress imposed on the fish by lead and could be used as indices of lead poisoning.
\end{abstract}

Keywords: Lead; Hyperglycemia; Cholesterol; Protein; Leukocyte

\section{Introduction}

Lead $(\mathrm{Pb})$ is one of the most widely used heavy metals that has wide applications in such products as storage batteries (lead accumulator), electric cable sheaths, alloys, pesticides, paints, petrol and rubber products among other uses [1]. In water bodies, $\mathrm{Pb}$ forms complexes with sediments or organic materials [2]. and in the process enters the food chain. The problem posed by $\mathrm{Pb}$ in the aquatic system is complex due to its non-degradability and interactions with other materials to form complexes that may potentiate their toxic effects [3] Lead deposits in various fish organs: liver, kidneys and spleen, but also digestive tract and gills [4]. Accumulation of lead in different fish species has been determined in several works [5], leading to disorders in fish body. When C. batrachus exposed to $5 \mathrm{ppm}$ of lead nitrate for 150 days, it exhibited marked inhibition of gonadal growth and showed decrease in cholesterol and lipid levels in brain, testis and ovary whereas the liver showed an elevation of both observed a very high number of red let cells (RCs) in the epidermis of common carp and rainbow trout kept in lead polluted water [6,7]. Hepatocyte vacuolization, hepatic cirrhosis, necrosis, shrinkage, parenchyma degeneration, nuclear psychosis and increase of sinusoidal spaces were the distinct changes observed in the liver of lead-exposed fish [8]. The characteristic symptoms of chronic lead toxicity include changes in the blood parameters with severe damage to erythrocytes and leucocytes and damage in the nervous system [9]. Low levels of $\mathrm{Pb}$ pollution could cause some adverse effects on fish health and reproduction [10]. Also, lead was found to impair the embryonic and larval development of fish species $[11,12]$ monitored the effect of lead on the Chinese sturgeon, Acipenser sinensis. They observed deformities as body (spinal) curvatures. The authors also reported reduced ability of locomotion and foraging by deformed juveniles. The purpose of the study was therefore to investigate the effect of sub lethal lead on the leucocyte and some biochemical parameters in grey mullet
Mugil cephalus, L - with a view to using them as biomarkers of lead toxicity.

\section{Materials and Methods \\ Collection and handling of experimental of fish}

The fish fingerlings were bought from Fish Farms at Manzalla lake Damietta, and transported to a wet laboratory in two $50 \mathrm{~L}$ plastic fish transport containers during march 2015. Once in the wet laboratory, fish was introduced into $200 \mathrm{~L}$ plastic containers for acclimatization for two week. The water was continually aerated to ensure that the dissolved oxygen level remained above $6 \mathrm{mg} / \mathrm{L}$ and fish were fed on a $32 \%$ crude protein diet at $3 \%$ body weight daily at $10.0 \mathrm{~h}$. The laboratory water was analyzed for different physico-chemical parameters (APHA, 2010) and lead. No fish mortality was recorded during acclimatization. The LC50 value for lead was statistically determined [13].

\section{Experimental design and in vivo studies}

One hundred and twenty fingerlings of Mugil cephalus L, (mean length of $12.00 \pm 2.25 \mathrm{~cm}$ and average weight of $35 \pm 3.20 \mathrm{~g}$ ) were used

*Corresponding author: Hussien M. El-Shafei, General Authority for Fish Resource Development, Egypt, Tel: 002-012-10965203; E-mail: hussienelshafei50@yahoo.com

Received January 06, 2017; Accepted April 24, 2017; Published April 29, 2017

Citation: El-Shafei HM (2017) Alterations in the Leucocytes and Serum Biochemistry in Grey Mullet (Mugil cephalus L,) Fingerlings Exposed to Sub lethal Doses of Lead for Different Exposure Periods. J Aquac Res Development 8: 473 doi: 10.4172/2155-9546.1000473

Copyright: () 2017 El-Shafei HM. This is an open-access article distributed unde the terms of the Creative Commons Attribution License, which permits unrestricted use, distribution, and reproduction in any medium, provided the original author and source are credited. 
for this study. They were divided into three groups of forty fingerlings per each. Each group was further divided into two replicates, twenty fish per replicate. Fish were exposed to $0.1 \mathrm{mg} \mathrm{Pb} / \mathrm{L}$ and the second group was exposed to $0.4 \mathrm{mg} \mathrm{Pb} / \mathrm{L}$. The third group was exposed to tap water only and it served as control group. The water in the experiment was changed every day to maintain the same $\mathrm{Pb}$ concentrations. Three fish from each replicate experiment was killed every seven days for twenty-eight days for the analysis.

\section{Blood collection}

The blood of the fish was collected every seven days through both cardiac puncture [14]. The blood was collected into three different vials. One of the vials containing fluoride oxalate was use to collect blood used for glucose determination. The other two vials were without anticoagulant and were used to collect the blood for the biochemical test, and thin blood smear.

\section{White Blood Cell Count (WBCc)}

The leucocyte count was done using the Neubauer microscopic counter after diluting the blood with Turk's dilution fluid. The differential white blood cell count was done by preparing a thin blood smear and staining same with Geimsa Romanosky stain [15]. The stained blood was left for 25 minutes for the Geimsa stain to act on it. Thereafter the stained blood was flooded with distilled water and rocked gently to evenly mix the distilled water and stain. The stained blood was washed with water and allowed to dry. The slide was viewed with a binocular microscope to identify the leukocyte species which was calculated as a percentage.

\section{Biochemical analyses}

The blood serum was obtained by centrifuging the blood sample at $5000 \mathrm{rpm}$ for five minutes and the protein in the samples was spectrophotometrically determined using Biuret method [16] at 540 $\mathrm{nm}$. The blood glucose was determined by determination of sugars in the blood and spinal fluid by anthrone reagent [17] method and the cholesterol concentration was determined by the method of estimation of total cholesterol in the serum and demonstration of its specificity [18].

\section{Statistical analysis}

The data was statistically analyzed using two way analysis of variance (ANOVA) followed by LSD post hoc test at $95 \%$ confidence interval [19].

\section{Results}

Water quality parameters, cations, anions, and background metals in acclimation were presented in Table 1

\section{Leukocyte response}

The changes in the total leucocytes and differential white blood cell count $\mathrm{Pb}$ - exposed to Fish are presented in (Table 2). The leucocytes count in the control group did not vary $(\mathrm{p}>0.05)$ significantly during the study. The leucocytes count increased significantly with increasing $\mathrm{Pb}$ concentrations and exposure period. Five different subspecies of leucocytes (lymphocytes, monocytes, neutrophils, eosinophils and basophils) were identified in the fish during the study. The lymphocyte and the monocytes constituted a granulocyte identified while neutrophil, eosinophils and basophils were the granulocytes recorded due to the presence of granules in their cytoplasm. The lymphocytes were the most abundant leucocytes group identified in the blood of the

\begin{tabular}{|c|c|}
\hline Parameters & Acclimation water \\
\hline Temperature $\left({ }^{\circ} \mathrm{C}\right)$ & $25 \pm 1{ }^{\circ} \mathrm{C}$ \\
\hline $\mathrm{pH}$ & $8.1 \pm 0.2$ \\
\hline Dissolved oxygen $(\mathrm{mg} / \mathrm{l})$ & $8.2-8.9$ \\
\hline Total Hardness $(\mathrm{mg} / \mathrm{l} \mathrm{as} \mathrm{CaCO} 3)$ & 106.2 \\
\hline Total alkalinity $(\mathrm{mg} / \mathrm{l}$ as CaCO3) & 42.8 \\
\hline Total dissolved solids $(\mathrm{mg} / \mathrm{l})$ & 173 \\
\hline Sodium $(\mathrm{mg} / \mathrm{l})$ & 5.0 \\
\hline Calcium $(\mathrm{mg} / \mathrm{l})$ & 31.0 \\
\hline Potasuim $(\mathrm{mg} / \mathrm{l})$ & 0.6 \\
\hline Magnesium $(\mathrm{mg} / \mathrm{l})$ & 6.1 \\
\hline $\mathrm{Cl}-(\mathrm{mg} / \mathrm{l})$ & 10.5 \\
\hline $\mathrm{NH} 3(\mathrm{mg} / \mathrm{l})$ & 0.034 \\
\hline SO4 $(\mathrm{mg} / \mathrm{l})$ & 13.0 \\
\hline PO4 $(\mathrm{mg} / \mathrm{l})$ & 0.03 \\
\hline Copper $(\mu \mathrm{g} / \mathrm{l})$ & 0.63 \\
\hline lead $(\mu \mathrm{g} / \mathrm{l})$ & 0.015 \\
\hline Zinc $(\mu \mathrm{g} / \mathrm{l})$ & $0 . .35$ \\
\hline
\end{tabular}

Table 1: Water quality parameters, cations, anions, and background metals in acclimation.

fish exposed to lead acetate. Both small and large lymphocytes were found during the study and they accounted for more than $80 \%$ of the white blood cells. The lymphocytes increased significantly $(\mathrm{p}<0.05)$ in the lead-exposed fish when compared with the control group. The lymphocytes were significantly different $(p>0.05)$ in the treatment groups and the lymphocytosis was both concentration and duration dependent. The monocytes decreased in the lead-exposed fish on the $7^{\text {th }}$ day and thereafter, it increased significantly in the treatment groups $(\mathrm{p}<0.05)$ when compared with the control group. The basophiles were the most abundant granular leucocytes in the peripheral blood of Mugil cephalus, L- exposed to lead acetate. The proportion was highest in the first week and on day 21 of the study. The neutrophils are the second largest granular white blood cell in the fish while the eosinophils are the least abundant subpopulation.

\section{Effect on serum glucose}

The glucose concentration in the control group did not vary throughout the study (Table 3 ). The serum glucose level on day 7 were $26.50 \pm 2.12 \mathrm{~g} / \mathrm{dL}$ and $30.50 \pm 0.70 \mathrm{~g} / \mathrm{dL}$ in the fish exposed to 0.1 and $0.4 \mathrm{mg} \mathrm{Pb} / \mathrm{L}$, respectively. On day 28 , the serum glucose concentrations were $52.50 \pm 2.12$ and $70.00 \pm 2.83 \mathrm{~g} / \mathrm{dL}$ in the groups exposed to 0.1 and $0.4 \mathrm{mg} \mathrm{Pb} / \mathrm{L}$ lead, respectively. There was concentration and duration significant increase $(\mathrm{p}<0.05)$ in the treatment groups when compared with the control and the values differed also in the treatment groups $(\mathrm{p}<0.05)$ at each sampling period.

\section{Effect on serum protein}

The results showed that the protein level in the control did not vary ( $\mathrm{p}>0.05$ ) throughout the study while the serum protein in the $\mathrm{Pb}-$ exposed fish did not differ $(p>0.05)$ from the control value during the first 14 days (Table 3). Generally, there was progressive concentration and duration dependent increases in the serum protein in the $\mathrm{Pb}$ exposed fish as it increased from $4.04 \pm 0.06 \mathrm{mg} / \mathrm{dL}$ on day 7 to 5.30 $\pm 0.05 \mathrm{mg} / \mathrm{dL}$ on day 28 in the fish exposed to $0.1 \mathrm{mg} \mathrm{Pb} / \mathrm{L}$. When the fish treated with $0.4 \mathrm{mg} \mathrm{Pb} / \mathrm{L}$, the serum protein increased from 4.45 $\pm 0.37 \mathrm{mg} / \mathrm{dL}$ on day 7 to $6.18 \pm 0.19 \mathrm{mg} / \mathrm{dL}$ on day 28 , respectively. Statistical analysis showed that serum protein levels in the treatment groups differed significantly $(\mathrm{p}<0.05)$ at the end of the study. 
Citation: El-Shafei HM (2017) Alterations in the Leucocytes and Serum Biochemistry in Grey Mullet (Mugil cephalus L,) Fingerlings Exposed to Sub lethal Doses of Lead for Different Exposure Periods. J Aquac Res Development 8: 473. doi: 10.4172/2155-9546.1000473

Page 3 of 5

\begin{tabular}{|c|c|c|c|c|c|}
\hline \multirow{2}{*}{ Leucocyte species } & \multirow{2}{*}{$\begin{array}{c}\text { Concentration } \\
\mathrm{Pb}(\mathrm{mg} / \mathrm{L})\end{array}$} & \multicolumn{4}{|c|}{ Duration } \\
\hline & & 7 days & 14 days & 21 days & 28 days \\
\hline \multirow{3}{*}{ Lymphocyte } & Control & $81.00 \pm 1.41 \mathrm{a}^{1}$ & $80.50 \pm 3.54 \mathrm{a} 1^{1}$ & $80.00 \pm 1.41 a^{1}$ & $85.50 \pm 0.71 a^{1}$ \\
\hline & 0.10 & $83.50 \pm 2.12 b^{1}$ & $84.50 \pm 0.71 b^{2}$ & $85.50 \pm 2.12 b^{3}$ & $387.50 \pm 3.54 b^{4}$ \\
\hline & 0.40 & $83.50 \pm 2.12 b^{1}$ & $86.00 \pm 2.83 b^{2}$ & $87.00 \pm 1.41 c^{3}$ & $87.00 \pm 1.41 b^{4}$ \\
\hline \multirow{3}{*}{ Monocyte (\%) } & Control & $2.50 \pm 0.71 a^{1}$ & $2.30 \pm 1.41 \mathrm{a}^{1}$ & $2.40 \pm 0.71 \mathrm{a}^{1}$ & $2.50 \pm 0.71 \mathrm{a}^{1}$ \\
\hline & 0.10 & $1.00 \pm 1.41 b 1^{2}$ & $5.50 \pm 1.41 b^{2}$ & $6.00 \pm 1.41 b^{2}$ & $4.00 \pm 0.00 \mathrm{~b}^{2}$ \\
\hline & 0.40 & $0.50 \pm 0.71 \mathrm{c} 1^{3}$ & $6.00 \pm 2.83 c^{2}$ & $5.00 \pm 1.41 c^{3}$ & $5.50 \pm 1.41 c^{3}$ \\
\hline \multirow{3}{*}{ Neutrophil (\%) } & Control & $1.50 \pm 0.71 \mathrm{a}^{1}$ & $1.50 \pm 0.71 \mathrm{a}^{1}$ & $1.50 \pm 0.71 \mathrm{a}^{1}$ & $1.30 \pm 0.71 \mathrm{a}^{1}$ \\
\hline & 0.10 & $1.00 \pm 1.41 b^{1}$ & $2.00 \pm 1.41 b^{2}$ & $1.50 \pm 0.71 a^{3}$ & $1.50 \pm 0.71 a^{3}$ \\
\hline & 0.40 & $0.50 \pm 0.71 \mathrm{c} 1^{3}$ & $1.50 \pm 0.71 c^{2}$ & $0.50 \pm 0.71 b^{1}$ & $2.00 \pm 1.41 b^{3}$ \\
\hline \multirow{3}{*}{ Eosinphil (\%) } & Control & $0.50 \pm 0.71 \mathrm{a}^{1}$ & $0.50 \pm 0.71 \mathrm{a}^{1}$ & $0.60 \pm 0.71 \mathrm{a}^{1}$ & $0.50 \pm 0.71 \mathrm{a}^{1}$ \\
\hline & 0.10 & $0.50 \pm 0.71 \mathrm{a}^{1}$ & $1.00 \pm 1.41 b^{2}$ & $0.50 \pm 0.71 \mathrm{a}^{1}$ & - \\
\hline & 0.40 & - & $0.50 \pm 0.71 \mathrm{a}^{1}$ & $0.50 \pm 0.71 \mathrm{a}^{1}$ & $0.50 \pm 0.71 \mathrm{a}^{1}$ \\
\hline \multirow{3}{*}{ Basophil (\%) } & Control & $10.50 \pm 0.71 \mathrm{a}^{1}$ & $10.50 \pm 2.12 \mathrm{a}^{1}$ & $9.80 \pm 2.12 \mathrm{a}^{1}$ & $10.50 \pm 2.12 \mathrm{a}^{1}$ \\
\hline & 0.10 & $15.50 \pm 0.71 \mathrm{a}^{1}$ & $5.50 \pm 0.71 b^{2}$ & $8.50 \pm 0.71 b^{2}$ & $7.00 \pm 2.83 b^{3}$ \\
\hline & 0.40 & $15.50 \pm 0.71 a^{1}$ & $6.00 \pm 2.83 c 2^{3}$ & $7.00 \pm 4.24 c^{3}$ & $7.00 \pm 1.41 b^{3}$ \\
\hline \multirow{3}{*}{ Leucocyte $\left(\times 10^{4} / \mathrm{mm}\right)$} & Control & $2.47 \pm 0.08 a^{1}$ & $2.50 \pm 0.02 a^{1}$ & $2.49 \pm 0.16 \mathrm{a}^{1}$ & $2.47 \pm 0.04 \mathrm{a}^{1}$ \\
\hline & 0.10 & $2.54 \pm 0.04 b^{1}$ & $3.38 \pm 0.60 b^{2}$ & $4.28 \pm 0.11 b^{3}$ & $4.84 \pm 0.01 b^{4}$ \\
\hline & 0.40 & $2.94 \pm 0.10 b^{1}$ & $3.96 \pm 0.06 c^{2}$ & $4.55 \pm 0.19 c^{3}$ & $5.55 \pm 0.04 \mathrm{c}^{4}$ \\
\hline
\end{tabular}

Values in the same column with the same superscript (lower case) are not significantly different $(p=0.05)$ between different concentrations within the same exposure duration. Values with different numeric superscripts differ significantly $(\mathrm{P}=0.05)$ between different exposure periods within the same concentration.

Table 2: Effect of different lead concentration on the differential white blood cell count of grey mullet Mugil cephalus $\mathrm{L}$.

\begin{tabular}{|c|c|c|c|c|c|}
\hline \multirow{2}{*}{ Parameters } & \multirow{2}{*}{$\begin{array}{l}\text { Concentration } \\
(\mathrm{mg} / \mathrm{L})\end{array}$} & \multicolumn{4}{|c|}{ Duration } \\
\hline & & 7 days & 14 days & 21 days & 28 days \\
\hline \multirow{3}{*}{ Glucose (mg/dL) } & Control & $17.25 \pm 2.08$ & $17.6 \pm 18$ & $17.4 \pm 18$ & -- \\
\hline & 0.10 & $26.50 \pm 2.12$ & $32.45 \pm 3.12$ & $41.52 \pm 08.12$ & $52.50 \pm 2.12$ \\
\hline & 0.40 & $30.50 \pm 0.70$ & 44. $60 \pm 4.12$ & $56.40 \pm 3.12$ & $70.00 \pm 2.83$ \\
\hline \multirow{3}{*}{ Cholesterol (mg/dL) } & Control & $54.06 \pm 4.50$ & $55.06 \pm 6.40$ & $56.06 \pm 3.52$ & $57.05 \pm 5.40$ \\
\hline & 0.10 & $122.5 \pm 3.53$ & $156.5 \pm 4.63$ & $187.4 \pm 2.50$ & $214.0 \pm 1.80$ \\
\hline & 0.40 & $152.5 \pm 3.54$ & $197.5 \pm 2.51$ & $243.5 \pm 3.53$ & $308 \pm 5.19$ \\
\hline \multirow{3}{*}{ Total Protein (g/dL) } & Control & $3.9 \pm 05$ & $4.1 \pm 03$ & $4.1 \pm 0.03$ & $4.1 \pm 01$ \\
\hline & 0.10 & $4.06 \pm 0.06$ & $17.6 \pm 18$ & $4.72 \pm 0.06$ & $5.28 \pm 0.05$ \\
\hline & 0.40 & $4.54 \pm 0.37$ & $32.45 \pm 3.12$ & $5.14 \pm 0.06$ & $38 \pm 0.19$ \\
\hline
\end{tabular}

Table 3: Change in some biochemical parameters in grey mulle Mugil cephalus $\mathrm{L}$ exposed to different $\mathrm{Pb}$ doses for different exposure periods days.

\section{Effect on serum cholesterol}

The serum cholesterol level in the control group did not vary $(\mathrm{p}<0.05)$ throughout the study (Table 3$)$. When compared with the control group, the cholesterol concentration was significantly higher $(\mathrm{P}<0.05)$ in the $\mathrm{Pb}$-exposed fish. Also, the cholesterol level differed significantly $(\mathrm{p}<0.05)$ in the treatment groups throughout the study. The cholesterol concentration increased significantly from $113.5 \pm$ $3.53 \mathrm{mg} / \mathrm{dL}$ on day 7 to $208.0 \pm 1.80 \mathrm{mg} / \mathrm{dL}$ on day 28 in the group exposed to $0.1 \mathrm{mg} \mathrm{Pb} / \mathrm{L}$. When the fish was exposed to $0.4 \mathrm{mg} \mathrm{Pb} / \mathrm{L}$, the cholesterol concentration increased significantly from $131.5 \pm 3.54 \mathrm{mg} /$ $\mathrm{dL}$ in the first week to $288 \pm 5.19 \mathrm{mg} / \mathrm{dL}$ on $28^{\text {th }}$ day of the study.

\section{Discussion}

The results of the study show that lead has significant effects on the leucocyte count of Mugil cephalus L- and the small lymphocytes decreased in number while the neutrophils increased. On the contrary, Svobodova et al. [20] found decreased leucocyte counts in Clarias gariepinus exposed to $0.45 \mathrm{mg} \mathrm{Pb} / \mathrm{L}$ for 4 to 5 days. The general leucocytosis reported in this study is consistent with the observation of Annune and Ahuma [21] in the dogfish exposed to $50 \mu \mathrm{g} / \mathrm{L}$ Cd for 4 days.

Changes of blood glucose are a good indicator of metal stress in fish [22] and alterations in the glucose level might be related to renal injury, liver damage, and lack of nutrition [23]. This study showed a dosedependent increase of glucose level after first 15 days. The observed increase in the serum glucose level in Mugil cephalus L, exposed to lead in this study is in accord with report of some earlier workers. Similar increase in plasma glucose was also reported in Prochidolus lineatus exposed to lead [24] and in Oreochromis niloticus exposed to copper [25]. It has been widely reported that hyperglycaemia in fish arises due to the stimulation of catecholamines and corticosteroids [26].

The increased serum glucose level in this study is an evidence of stress due to lead exposure as Brown [27] argued that coping with such stress is an energy demanding process that requires the fish to mobilize metabolically energy substrates through intense gluconeogenesis. Glucose being one of such known substrates is mobilized through gluconeogenesis to meet this challenge [28]. Heavy metals have been reported to act antagonistically with glucocorticoids by inhibiting the receptors thereby disrupting the osmotic and mineral regulatory mechanisms [29]. Serum increase in glucose due to toxicants has have been associated with hypothalamus-sympathetic-chromaffin cells [30] instead of the hypothalamus-pituitary-internal axis [31] that is known to have tremendous influence on carbohydrate metabolism.

The results of this study showed that the serum total protein increased significantly in Mugil cephalus L, exposed to lead. Similar increases in the serum protein level were reported in Oreochromis 
Citation: El-Shafei HM (2017) Alterations in the Leucocytes and Serum Biochemistry in Grey Mullet (Mugil cephalus L,) Fingerlings Exposed to Sub lethal Doses of Lead for Different Exposure Periods. J Aquac Res Development 8: 473. doi: 10.4172/2155-9546.1000473

niloticus exposed to metals [27]. Also increased plasma protein was reported in Mugil exposed to 0.5ppm copper and cadmium [32]. On the contrary, decreased tissue protein was reported in Oreochromis niloticus treated with cadmium [33] and in Cyprinus carpio when exposed to heavy metals [34].

The enhanced serum cholesterol in this study is an indication of hypercholesteremia in the fish due to the stimulatory effect on the cholesterol biosynthetic pathway. Reduced serum cholesterol level has been reported in Oreochromis niloticus exposed to some heavy metals $[27,35]$ and in Lepomis macrochirus exposed to methyl mercuric chloride [36]. Cholesterol concentration in the serum of cadmium exposed fish also showed a different pattern. Another study showed a reduction in cholesterol within 15-days, possibly due to tissue damage in the kidney [37]. On the contrary, in Oreochromis niloticus, an increase in cholesterol was seen during a 21 day period due to cadmium [38].

This alteration in cholesterol concentration could be due to hazardous effects of metals on cell membrane. The observed elevated cholesterol in this study could have resulted in part to the adverse effect of lead on the liver leading to altered cholesterol metabolism resulting in increased serum cholesterol. This according to Oner et al. [38] could be due to liver and kidney failure that resulted in the release of cholesterol into the blood stream. Thus, increase in cholesterol levels are good indicators of environmental stress in fishes.

\section{Conclusion}

Generally, the leucocytosis observed in this study gives indication that exposing the fish to lead predisposes it to secondary infections. Also, the reported hyperglycemia, increased serum protein and cholesterol levels are indications of altered carbohydrate, lipid and protein metabolism in the fish due to lead exposure. Serum parameters which provide information as to state of the internal environment of the fish are known to respond quickly to changes in the water quality. The changes in these biomarkers are a reflection of organ dysfunction in the fish due to metal exposure and these biomarkers could be used in ecotoxicological assessment and as early warning indicators of pollution.

\section{References}

1. Jackson RN, Baird D, Els S (2005) The effect of the heavy metals lead and zinc on the brood and larval development of the burrowing crustacean, Calliianassa kranssi. 31: 107-116.

2. TNO Report (2001) Risk to health and the environment related to the use of lead in products. TNO Strategy, Technology and Policy. STB-01-39.

3. ATSDR (1999) Toxicological profile for lead (Update) Prepared by Research Triangle institute.

4. Jezierska B, Witeska M (2006) The metal uptake and accumulation in fish living in polluted waters. NATO Science Series, The Netherlands: Springe.

5. Castro-González MI, Méndez-Armenta M (2008) Heavy metals: Implications associated to fish consumption. Environ. Toxicol Pharmacol 26: 263-271.

6. Katti SR, Sathyanesan AG (1983) Lead nitrate induced changes in lipid and cholesterol levels in the freshwater fish Clarias batrachus. Toxicol Lett 19: 93-96.

7. Iger $Y$, Abraham M (1997) Rodlet cells in the epidermis of fish exposed to stressors. Tissue Cell 29: 431-438.

8. Olojo EAA, Olurin KB, Mbaka G, Oluwemimo AD (2005) Histopathology of the gill and liver tissues of the African catfish, Clarias gariepinus exposed to lead. Afr J Biotechnol 4: 117-122

9. El-Badawi AA (2005) Effect of lead toxicity on some physiological aspects of Nile tilapia fish, Oreochromis niloticus. Inter Conf Vet Res Div, NRC, Cairo, Egypt.
10. Delistraty D, Stone A (2007) Dioxins, metals, and fish toxicity in ash residue from space heaters burning used motor oil. Chemosphere 68: 907-914.

11. Dave G, Xiu R (1991) Toxicity of mercury, copper, nickel, lead, and cobalt to embryos and larvae of zebrafish, Brachydanio rerio. Arch Environ Contam Toxicol 21: 126-134.

12. Hou JL, Zhuang P, Zhang LZ, Feng L, Zhang T, et al. (2011) Morphological deformities and recovery, accumulation and elimination of lead in body tissues of Chinese sturgeon, Acipenser sinensis, early life stages: A laboratory study. J Appl Ichthyol 27: 514-519.

13. Finney DJ (1971) Probit analysis, (3rd edn) Cambridge University Press Cambridge.

14. El-Sherif MS, Ahmed M, El-Danasoury MA, El-Nwishy NHK (2009) Evaluation of diazinon toxicity on Nile tilapia (Oreochromis niloticus). J Fish Aquat Sci 4 169-177.

15. Puchkov N (1964) The white blood cell. In: The Technique For the Investigation of Fish Physiology, Jerusalem.

16. Gornall AG, Bardawill CJ, David MN (1949) Determination of serum protein by means of the buiret reaction. J Biol Chem 177: 751-766.

17. Roe JH (1955) Determination of sugars in the blood and spinal fluid by anthrone reagent. J Biol Chem 212: 335-343

18. Abell LL, Ley BB (1952)A simplified method for the estimation of total cholestero in the serum and demonstration of its specificity. J Biol Chem 195: 357.

19. Steel RGD, Torrie JH (1960) Principles and procedures of statistics. McGrawHill Book. New York.

20. Svobodova Z, Vykasova B, Machova J (1994) Sub-lethal chloride effects of pollutants on freshwater fish.

21. Annune PA, Ahuma FTA (1998) Haematological changes in mud catfish, Clarias gariepinus (Burch.) exposed to sub-lethal concentrations of copper and lead. J Aquat Sc 13: 33-36.

22. Tort L, Hernandes-Pascual MD (1990) Haematological effects in dogfish (Scyliorhinus canicula) after short term sub-lethal cadmium exposure. Acta Hydrochim Hydrbiol 18: 379-383.

23. Gagnon A, Jumarie C, Hontela A (2006) Effects of Cu on plasma cortisol and cortisol secretion by adrenocortical cells of rainbow trout (Oncorhynchus mykiss). Toxicol 78: 59-65.

24. Pratap HB, Wendelaar BSE (1990) Effect of waterborne cadmium on plasma cortisol and glucose in the cichlid fish Oreochromis mossambicus. Comp Biochem Physiol 95: 313-317.

25. Martinez CBR, Nagae MY, Zaia CTBV, Zaia DAM (2004) Acute morphological and physiological effects of lead in the neotropical fish, Prochidolus lineatus. Braz J Biol 64: 797-807.

26. Monterio SM, Mancera JM, Fernandes AF, Sousa M (2005) Copper induced alterations of the biochemical parameters in the gill and plasma of Oreochromis niloticus. Comp. Biochem Physiol C 141: 375-383.

27. Brown JA (1993) Endocrine responses to environmental pollutants. Fish Ecophyiology. Chapman and Hull, London, UK.

28. Özgür F, Kargm F (2010) Individual and combined effects of heavy metals on serum biochemistry of Nile tilapia Oreochromis niloticus. Arch Environ Contam Toxicol 58: 151-157.

29. Vosyliene MZ (1999) The effect of heavy metals on haematological indices of fish. Act Zool Lith Hydro 9: 76-82.

30. Wendelaar-Bonga SE (1997) The stress response in fish. Physiol Rev 7 591-625.

31. McDonald G, Milligan L (1997) Ionic, osmotic and acid-base regulation in stress. Fish stress and Health in Aquaculture. Cambridge University Press Cambridge, USA.

32. Emad HAE, El-Moselhy KM, Mohamed AH (2005) Toxicity of cadmium and copper and their effect on serum biochemical parameters of marine fish Mugil scheli. Egyptian J Aquat Res 31: 60-71.

33. Arends RJ, Mancers JM, Munoz JL, Wendelaar-Bonga SE, Flik G (1999) The stress response of the gill of seabream (Sparus aurata L.) to air exposure and confinement. J Endocrionl 163: 149-157. 
Citation: El-Shafei HM (2017) Alterations in the Leucocytes and Serum Biochemistry in Grey Mullet (Mugil cephalus L,) Fingerlings Exposed to Sub lethal Doses of Lead for Different Exposure Periods. J Aquac Res Development 8: 473. doi: 10.4172/2155-9546.1000473

Page 5 of 5

34. Almeida JA, Novelli ELB, Dal-Pai SM, Alves-Junior R (2001) Environmental cadmium exposure and metabolic resposes of the Nile tilapia Oreochromis niloticus Environ Pollut 114: 169-175.

35. Ruparella SG, Werma Y, Saiyed SR, Rawal UM (1990) Effect of cadmium on blood of tilapia, Oreochromis mossambicus (Peters) during prolonged exposure. Bull. Environ. Contam Toxicol 45: 305-312

36. Dutta HM, Haghighi AZ (1986) Methylmercuric chloride and serum cholesterol levels in bluegill Lepomis macrochirus. Bull Environ Contam Toxicol 36: 181-185.

37. Saeed HM, Mozhdeh K, Amin N (2013) Effects of cadmium at sub-letha concentration on growth and biochemical parameters in rainbow trout (Oncorhynchus mykiss). Ir Vet J, 66: 11

38. Oner M, Atli G, Canli M (2008) Changes in serum parameters of freshwate fish Oreochromis niloticus following prolonged metal $(\mathrm{Ag}, \mathrm{Cd}, \mathrm{Cr}, \mathrm{Cu}, \mathrm{Zn})$ exposures. Environ Toxicol Chem 2: 360-366. 